\title{
Genotypic diversity and phenotypic traits of Streptococcus mutans isolates and their relation to severity of early childhood caries
}

Remberto Marcelo Argandoña Valdez ${ }^{1,2^{*}}$, Cristiane Duque ${ }^{2^{*}}$, Karina Sampaio Caiaffa ${ }^{2}$, Vanessa Rodrigues dos Santos², Maria Luiza de Aguiar Loesch², Natalia Helena Colombo², Rodrigo Alex Arthur ${ }^{3}$, Thais de Cássia Negrini ${ }^{3}$, Marcelo Fabiano Gomes Boriollo ${ }^{4,5}$ and Alberto Carlos Botazzo Delbem²

\begin{abstract}
Background: Early childhood caries (ECC) is an aggressive condition that can affect teeth of young children. This study aimed to evaluate genotypic diversity and phenotypic traits of $S$. mutans isolated from dental biofilms of children with different caries status in comparison with caries free (CF) children.

Methods: Streptococcus mutans strains were isolated from supragingival biofilm samples of CF, ECC and severe-ECC (S-ECC) children and genotyped by arbitrary-primer polymerase chain reaction - AP-PCR. S. mutans genotypes were tested for their ability to reduce the suspension $\mathrm{pH}$ through glycolysis, to tolerate extreme acid challenge and by their ability to form biofilm. Response variables were analyzed by ANOVA/Tukey or Kruskal-Wallis/Mann-Whitney tests at a $5 \%$ of significance.

Results: There was an increase in the prevalence of Streptococcus mutans in biofilms with the severity of dental caries. No differences in genotypic diversity and in acidogenicity of genotypes were found among CF, ECC and S-ECC children. S mutans strains with genotypes more characteristic for ECC and S-ECC children formed more biofilms than those identified in CF children. The strains isolated from S-ECC children were highly acid tolerant.
\end{abstract}

Conclusion: Although S. mutans genotypic diversity was similar among the groups of children, phenotypic traits of S. mutans, especially the acid tolerance response, could explain the severity of early childhood caries.

Keywords: Early childhood caries, Streptococcus mutans, Dental biofilm, Genotypic diversity, Acidogenicity, Aciduricity

\section{Background}

Dental caries is a biofilm-associated disease caused by frequent intake of dietary sugars. Fermentation of these sugars by biofilm microbiota leads to acid production, which disrupt microbial homeostasis and cause dissolution of tooth minerals [1]. Mutans streptococci, mainly Streptococcus mutans, have been considered as the most important bacteria implicated in dental caries etiology and progression. These microorganisms are frequently

\footnotetext{
*Correspondence: rembertoarg@hotmail.com; cduque@foa.unesp.br; cristianeduque@yahoo.com.br

${ }^{1}$ Universidad Mayor de San Andrés (UMSA), Foundation Pro-Joven, La Paz, La Paz, Bolivia

${ }^{2}$ Department of Pediatric Dentistry and Public Health, São Paulo State University (UNESP), School of Dentistry, Araçatuba, R. José Bonifácio, 1193, Araçatuba, SP CEP: 16015-050, Brazil

Full list of author information is available at the end of the article
}

isolated from cavitated caries lesions and induce caries formation in sucrose-fed animals [2]. S. mutans has important features which contribute to their virulence, such as their ability to metabolize a wide variety of carbohydrates and produce large amounts of acid (acidogenicity), to tolerate extreme acidic environments (aciduricity) and ability to synthesize extracellular polysaccharides (EPS), mainly from sucrose, which improve their adherence to other microorganisms and to tooth surface [3].

Early childhood caries (ECC) is an aggressive condition of dental caries that affects young children. ECC is classified by The American Academy of Pediatric Dentistry (AAPD) as the presence of one or more decayed, missing (due to caries) or filled tooth surfaces in any primary tooth in a child 71 months of age or younger, while 
severe ECC (S-ECC) is represented by one or more cavitated, missing (due to caries) or filled smooth surface in primary maxillary anterior teeth or decayed, missing or filled surfaces greater than or equal to four (age of 3), five (age of 4) or six (age of 5) [4]. ECC disease has rampant, acute and progressive characteristics and lead to destruction of the primary dentition affecting negatively children's physical and mental health in addition to increase the risk of new caries lesions in the permanent dentition [5].

It is well known that saliva and dental biofilm harbors different genotypes of $S$. mutans and caries-active individuals seems to have more genotypes than caries-free ones [6-8]. Some studies evaluated genetic diversity of S. mutans from ECC children [8-14]. It has been discussed that the simultaneous action of several strains with possibly different cariogenic potential could increase the risk of caries [8]. Phenotypic traits of different $S$. mutans genotypes would be associated with their ability to colonize tooth surface or express factors that could induce the formation of caries lesions $[11,15]$. However, it is still unknown if genotypic diversity and phenotypic traits of $S$. mutans are related to different caries status or caries severity in children. Therefore, this study aimed to evaluate genotypic diversity, acidogenicity, aciduricity and biofilm formation of $S$. mutans isolated from dental biofilms of caries free (CF), of ECC and of S-ECC children in an effort to understand caries lesion development at individual level.

\section{Methods}

\section{Study design}

This study was approved by the Research Ethics Committee of Araçatuba Dental School, State University of Sao Paulo, Brazil (CAAE 0041.0.258.000-10). Signed informed consent was obtained from the parents/ legal tutors of children previously to the beginning of the study. Twenty and seven children enrolled in public preschools in peripherical area of the city of Araçatuba (São Paulo, Brazil) participated in the study. Children were included if they were in good general health, without syndromes or chronic systemic diseases. Children whose parents/ legal tutors refused to sign the informed consent, or who did not cooperate with the clinical exams, were excluded from the study. Dental examinations were conducted by one examiner $(\mathrm{CD})$ using a mouth mirror and a ball-ended dental probe under a focusable flashlight, after biofilm removal and drying with gauze. World Health Organization (WHO) criteria was used to classify children caries status, considering the total number of decayed, missing or filled teeth surfaces (dmfs). Children were divided into three groups according to their caries status (CF, ECC, and S-ECC) according to AAPD guidelines [4]. All children with dental caries were submitted to restorative/surgical treatment performed by a pediatric dentist, after samples collection.

\section{Samples collection and microbiological procedures}

Supragingival biofilm from CF, ECC and S-ECC children were collected from all buccal and lingual smooth intact surfaces at least $1 \mathrm{~h}$ after food intake. Biofilm samples were pooled in order to have a representative sample of each individual. No biofilm was collected from caries cavities in order to avoid contamination with $S$. mutans strains harboring this environment. In order to standardize the amount of biofilm, a sterilized plastic disposable handle (Greiner, Frickenhausen, Germany) with a circular opening of about $1 \mu \mathrm{L}$ of volume capacity was used for biofilm collection immediately after sample pooling. Biofilm samples were placed in $1 \mathrm{ml}$ of TE buffer $(10 \mathrm{mM}$ Tris- $\mathrm{HCl}, 1 \mathrm{mM}$ EDTA, pH 8.0) that was kept on ice for no longer than $2 \mathrm{~h}$. Biofilm suspensions were vortexed for $1 \mathrm{~min}$, an aliquot of each sample was serially diluted in $0.9 \% \mathrm{NaCl}$ sterile solution and plated on Mitis Salivarius Agar with 0.2 U Bacitracin (Sigma Aldrich) for the isolation of mutans streptococci (MS) [10]. All agar plates were incubated at $37^{\circ} \mathrm{C}$ for $48 \mathrm{~h}$ in an atmosphere of $5 \% \mathrm{CO}_{2}$. The number of colonyforming units (CFU) was determined from a representative area of each agar plate yielding 30-300 colonies using a stereoscopic microscope and the results were expressed as $\mathrm{CFU} / \mathrm{ml}$. Up to six representative colonies of MS were then selected from agar plates and individually transferred to tubes containing $5 \mathrm{~mL}$ of Brain Heart Infusion broth (BHI) which were incubated for $24 \mathrm{~h}$ under the same conditions described above. The purity of the cultures was checked by Gram-staining. Aliquots of MS isolated strains were frozen at $-20{ }^{\circ} \mathrm{C}$ in $\mathrm{BHI}$ containing $20 \%$ glycerol for further use in molecular analysis [13].

\section{Genotypic analysis}

\section{DNA extraction and Polymerase Chain Reaction (PCR)}

Frozen aliquots of each MS colony isolated from biofilms were grown on MSB (Mitis Salivarius Agar with bacitracin, as described above) and incubated $37{ }^{\circ} \mathrm{C}$ for 24-48 $\mathrm{h}$ in an atmosphere of $5 \% \mathrm{CO}_{2}$. The colonies that grew on BHI agar were incubated into BHI broth (Difco) and incubated at $37^{\circ} \mathrm{C}$ for $18 \mathrm{~h}$ at the same conditions. Cells from these cultures were then harvested and genomic DNA of MS isolates was extracted using a protocol modified by Nascimento et al. [15]. Briefly, samples were submitted to a lysing solution (extraction buffer and proteinase $\mathrm{K}$ ) and then purified using chloroform:isoamil-alcohol, followed by DNA precipitation with isopropanol and $70 \%$ ethanol. The DNA was resuspended in TE buffer (10 mM Tris-Hcl, $0.1 \mathrm{mM}$ EDTA, pH 7.5, with $10 \mathrm{mg} / \mathrm{mL}$ RNAse). DNA was quantified in a spectrophotometer at $260 \mathrm{~nm}$ for obtaining a standard concentration of $100 \mathrm{ng}$ of $\mathrm{DNA} / \mathrm{mL}$ from each isolate. 
DNA samples were stored at $-70{ }^{\circ} \mathrm{C}$ for subsequent PCR reactions.

In order to confirm Streptococcus mutans molecular identity, DNA of MS isolates were submitted to PCR method, using specific primers for portions of the glucosyltransferase $B$ gene (gtfB) following the bases sequences: 5' - ACT ACA CTT TCG GGT GGC TTG G - 3' e 5' CAG TAT AAG CGC CAG TTT CAT C - 3', to amplify a 517 bp DNA fragment. Each PCR mixture contained $5 \mu \mathrm{l}$ of the DNA template, $5 \mu \mathrm{l}$ of X 10 PCR amplification buffer (100 mM Tris-HCl, $500 \mathrm{mM} \mathrm{KCl,} \mathrm{pH} \mathrm{8.3),} 0.2 \mathrm{mM}$ of dNTPs (DNA Polymerization Mix), $3.0 \mathrm{mM} \mathrm{MgCl}$, $1 \mu \mathrm{M}$ of each primer and $2.5 \mathrm{U}$ de Taq DNA Polymerase and sterile distilled water to obtain a final volume of $25 \mu \mathrm{l}$. Positive and negative controls of PCR reactions were purified genomic DNA of S. mutans (ATCC 25175) and sterile water, respectively. The amplification of DNA was performed in a thermocycler (GeneAmp PCR System 2400, Perkin Elmer, Applied Biosystems, USA) with an initial denaturation at $95^{\circ} \mathrm{C}$ for $5 \mathrm{~min}$, followed by 30 cycles of denaturation at $95^{\circ} \mathrm{C}$ for $30 \mathrm{~s}$, annealing at $59{ }^{\circ} \mathrm{C}$ for $30 \mathrm{~s}$ and extension at $72{ }^{\circ} \mathrm{C}$ for $1 \mathrm{~min}$, besides the final extension at $72{ }^{\circ} \mathrm{C}$ for $7 \mathrm{~min}$. The PCR amplification products were separated by electrophoresis in 2\% agarose gels in Tris-borate-EDTA (TBE) running buffer ( $\mathrm{pH} \mathrm{8.0)}$ at $100 \mathrm{~V}$ for $45 \mathrm{~min}$. Gels were stained with SYBR Green $1.6 \%$ and visualized under ultraviolet light illumination (UltraLum - Labtrade do Brasil). A 100 bp DNA ladder was included as a molecular-size marker in each gel. All PCR reagents were obtained from Invitrogen, Life Technologies, São Paulo, Brazil [16, 17].

\section{Arbitrary-Primed Polymerase Chain Reaction (AP-PCR)}

Isolates molecularly identified as Streptococcus mutans were genotyped by AP-PCR technique. Amplification was performed with primer OPA-02 (5' - TGCCGAGCTG $\left.3^{\prime}\right)$ [6]. All reactions were processed in a volume of $50 \mu \mathrm{l}$, containing $1 \times$ PCR buffer, $5 \mathrm{U} / \mu \mathrm{l}$ of Taq DNA polymerase, $10 \mathrm{mM}$ DNTp, $20 \mu \mathrm{M}$ primer, $50 \mathrm{mM} \mathrm{MgCl} 2$ and $2 \mu \mathrm{l}$ of template DNA [6]. The amplification was performed in the same thermocycler with an initial denaturation at $95{ }^{\circ} \mathrm{C}$ for $2 \mathrm{~min}$ and 45 cycles consisting of $94{ }^{\circ} \mathrm{C}$ for $30 \mathrm{~s}, 36{ }^{\circ} \mathrm{C}$ for $30 \mathrm{~s}$ and $72{ }^{\circ} \mathrm{C}$ for $1 \mathrm{~min}$, concluding with a final extension of $72{ }^{\circ} \mathrm{C}$ for 5 min [16]. Amplicons generated by AP-PCR were analyzed eletrophoretically in $1.5 \%$ agarose gel in TBE running buffer and stained with SYBR Gren 1.6\%. A $1 \mathrm{~Kb}$ DNA ladder was used as molecular-size marker. The gels were photographed and their images captured with a digital imaging system (Kodak Digital Science 1D). The molecular weights for each band or amplicon were computed and analyzed by the Sigma Gel software program $[16,17]$.

\section{Phenotypic analysis}

\section{Acidogenicity assays (glycolytic curves)}

Frozen stocks of $S$. mutans genotypes $(n=14(\mathrm{CF})$; $n=12$ (ECC); $n=8$ (S-ECC)) identified in the dental biofilms were grown on $\mathrm{BHI}$ agar plates and incubated at $37{ }^{\circ} \mathrm{C}$ for $48 \mathrm{~h}$ in an atmosphere of $5 \% \mathrm{CO}_{2}$. CFU were collected and inoculated into BHI broth, which was incubated at $37^{\circ} \mathrm{C}$ for $18 \mathrm{~h}$. These assays were conducted according protocol described by Arthur et al. [17], to evaluate the ability of $S$. mutans genotypes to lower the suspension $\mathrm{pH}$ through glycolysis ( $\mathrm{pH}$ drop). Aliquots of cultures (approximately $10^{8} \mathrm{CFU} / \mathrm{ml}$ ) grown in BHI broth were centrifuged and resuspended in $50 \mathrm{mM} \mathrm{KCl}$ supplemented with $1 \mathrm{mM} \mathrm{MgCl}_{2}$ (Fluka, Steinheim, Germany). The $\mathrm{pH}$ of the solution was adjusted to 7.2, and glucose was added to a final concentration of $55.6 \mathrm{mM}$. The decrease in $\mathrm{pH}$ was then assessed during $300 \mathrm{~min}$ using a glass electrode previously calibrated with $\mathrm{pH}$ standards ( $\mathrm{pH} 4.0$ and 7.0). The area under the curve (AUC) for the drop in $\mathrm{pH}$ after 300 min considering $\mathrm{pH} 3.0$ as a cut-off point was also determined. The acidogenicity was expressed as AUC (total $\mathrm{pH}$ drop) or means/standard deviation of $\mathrm{pH}$ for each period of time (0 to $300 \mathrm{~min}$ ). Analyses were performed in triplicate.

\section{Aciduricity assays (acid killing assays)}

The ability of $S$. mutans genotypes $(n=14(\mathrm{CF}) ; n=12$ (ECC); $n=8(\mathrm{~S}-\mathrm{ECC})$ ) to tolerate acid challenge was evaluated using the acid killing assay $[11,15,17,18]$. Briefly, aliquots (approximately $10^{8} \mathrm{CFU} / \mathrm{mL}$ ) grown for $18 \mathrm{~h}$ in BHI broth were transferred into fresh BHI broth and grown to mid-exponential phase $(\mathrm{OD} 550=0.5)$. The suspensions were then centrifuged, and the pellets were washed once with $0.1 \mathrm{M}$ glycine buffer ( $\mathrm{pH}$ 7.0) (Fluka). In addition, the washed pellets were resuspended in $0.1 \mathrm{M}$ glycine buffer $\mathrm{pH} 2.8,5.0$ and 7.0 (control). Immediately after resuspension (T0) and after $60 \mathrm{~min}$ (T60) of incubation at $37^{\circ} \mathrm{C}$, aliquots were serially diluted in phosphate buffer $(\mathrm{pH} 7.2)$, plated on BHI agar and incubated at $37^{\circ} \mathrm{C}$ for $48 \mathrm{~h}$ in an atmosphere of $5 \% \mathrm{CO}_{2}$. Cell viability at each time point was expressed as the percentage of bacterial growth in relation to T0 (100\%). Analyses were performed in triplicate.

\section{Biofilm assays}

Biofilm assays were conducted for $S$. mutans genotypes $(n=14$ (CF); $n=12$ (ECC); $n=8$ (S-ECC)) according to Mattos-Graner et al. [19] with slight modifications. An aliquot from a BHI broth culture of each MS isolate (prepared as described above) was diluted 1:100 in fresh $\mathrm{BHI}$, and $200 \mu \mathrm{l}$ of this dilution was transferred to sterile polystyrene U-bottom microtiter plates. Plates were incubated for $18 \mathrm{~h}$ at $5 \% \mathrm{CO}_{2}$, and biofilm growth was 
revealed and quantified by staining with crystal violet. Crystal violet absorbance was determined with a plate reader at $575 \mathrm{~nm}$ (Eon Microplate Spectrophotometer, BioTek Instruments, USA). The absorbance (A550) of planktonic cultures grown under the same conditions was measured to monitor growth. Biofilm formation for all strains was measured in triplicate plates.

\section{Statistical analysis}

The studied groups (CF, ECC and S-ECC) were considered as dependent variables. The constant "1" was added to CFU because no growth was detected in some samples. A counts were then transformed to $\log 10(\mathrm{CFU}+1)$. Age, dmfs, mutans streptococci counts, acidogenicity and biofilm assays were compared among the groups by ANOVA followed by Tukey tests. Data of cell viability from aciduricity assays were transformed to $\log _{10}$ due to data dispersion and expressed as the percentage of bacterial growth $(\mathrm{T} 60)$ in relation to time zero $(\mathrm{T} 0=100 \%)$ in $\mathrm{pH} 2.8, \mathrm{pH} 5.0$ and $\mathrm{pH}$ 7.0. Aciduricity and number of isolates and genotypes of $S$. mutans were compared among the groups by Kruskal-Wallis and Mann-Whitney tests. Electrophoretic bands previously scored in the APPCR gels were converted into binary data and submitted to NTSYS-pc software (Applied Biostatistics, Inc.), using coefficient SSM (Simple Matching Coefficient) and UPGMA cluster analysis (Unweighted Pair-Group method with Mathematic Average) to generate dendrogram showing genetic similarity among the bacterial strains isolated from CF, ECC and S-ECC children. Statistical analysis was performed using the program SPSS version 17.1. $(p<0.05)$.

\section{Results}

Twenty-seven children, 12 girls (44.5\%) and 15 boys (55.5\%) between 36 and 65 months of age (mean $45.21 \pm 12.04)$ were included in this study, corresponding to 10 (37.7\%) CF, 9 (33.4\%) ECC and 8 (29.6\%) SECC children. There was no statistical difference among $\mathrm{CF}, \mathrm{ECC}$ and S-ECC children regarding gender and age. Dmfs values differed statistically among the tested groups with S-ECC children presenting the highest values. Counts of MS in biofilms of ECC and S-ECC children did not differ from each other but they were higher than those found in CF children (Table 1).

One hundred and nine MS strains (38 for CF, 35 for ECC and 36 for S-ECC) were isolated from biofilms. Ninety-eight isolates were molecularly identified as $S$. mutans. S-ECC children presented the highest percentage of $S$. mutans isolates compared with CF and ECC children, which were not different between them (Table 1). Fiftynine out of $98 \mathrm{~S}$. mutans isolates (21 CF, $20 \mathrm{ECC}$ and 18 S-ECC) were re-isolated and genotyped by AP-PCR. A total of 22 clusters (identical or highly related) were detected in biofilm samples after analysis of dendrogram (Fig. 1). Although S-ECC children seems to harbor lesser genotypes compared to other groups, the number of genotypes found in biofilms was not statistically different among CF, ECC and S-ECC children (Table 1). Most of children (53.6\%) exhibited two different genotypes. One genotype was found in $35.7 \%$ of children, while three or more genotypes were present in $10.7 \%$ of children.

Regarding phenotypic analysis, no statistical difference was observed among the tested groups for acidogenicity of $S$. mutans genotypes considering both $\mathrm{pH}$ values at each time point (0 to $300 \mathrm{~min}$ ) and the values of area under the curve - AUC (Fig. 2; $p>0.05$ ). Final $\mathrm{pH}$ achieved by genotypes (mean $\pm \mathrm{SD}$ ) of CF children (3.84 \pm 0.48$)$ ranged from 4.67 to 3.48 ; from 4.0 to 3.47 for ECC children $(3.69 \pm 0.19)$ and from 3.75 to 3.51 for SECC children (3.63 \pm 0.12$)$, but no difference was found among the groups evaluated. Considering aciduricity, percentage of growth for $S$. mutans genotypes was not statistically different among CF, ECC and S-ECC children at pH 5.0 and 7.0 (Fig. 3). However, genotypes of S-ECC children presented higher percentage of growth compared with $\mathrm{ECC}$ and $\mathrm{CF}$ at $\mathrm{pH} 2.8$. Under exposure to $\mathrm{pH} 2.8$ for $60 \mathrm{~min}$, counts of viable cells of $S$. mutans were statistically lower than those found at $\mathrm{pH} 5.0$ and 7.0 for CF, ECC and S-ECC genotypes. Genotypes isolated from ECC and S-ECC children presented higher biofilm formation than those isolated from CF children (Fig. 4).

\section{Discussion}

In the present study, differences were not found in genotypic diversity among CF, ECC and S-ECC children.

Table 1 Description of the study population

\begin{tabular}{|c|c|c|c|c|}
\hline & CF & ECC & S-ECC & $p$ value \\
\hline Age (months; mean $\pm \mathrm{SD}$ ) & $44.4 \pm 8.19^{\mathrm{A}}$ & $45.88 \pm 9.42^{\mathrm{A}}$ & $46.37 \pm 6.32^{\mathrm{A}}$ & 0.67 \\
\hline $\mathrm{dmfs}^{*}($ mean $\pm \mathrm{SD})$ & $0^{A}$ & $3.11 \pm 1.83^{B}$ & $22.6 \pm 23.21^{C}$ & 0.00 \\
\hline S. mutans isolates $n(\%)^{* *}$ & $30(78.9)^{\mathrm{a}}$ & $32(91.42)^{a, b}$ & $36(100)^{b}$ & 0.00 \\
\hline Total S. mutans genotypes (identical genotypes) & $21(14)^{a}$ & $20(12)^{a}$ & $18(8)^{a}$ & 0.62 \\
\hline
\end{tabular}

*dmsf: tooth surfaces with caries (decay), indicated for extraction (missing) and filled

${ }^{A}$ Different uppercase letters shows statistical difference among CF, ECC and S-ECC groups, according to ANOVA/Tukey tests ( $p<0.05$ )

${ }^{a}$ Different lower case letters shows statistical difference among CF, ECC and S-ECC groups, according to Kruskal-Wallis and Mann-Whitney tests ( $p<0.05$ )

**Percentage calculated in relation to total number of MS isolated in each tested condition 


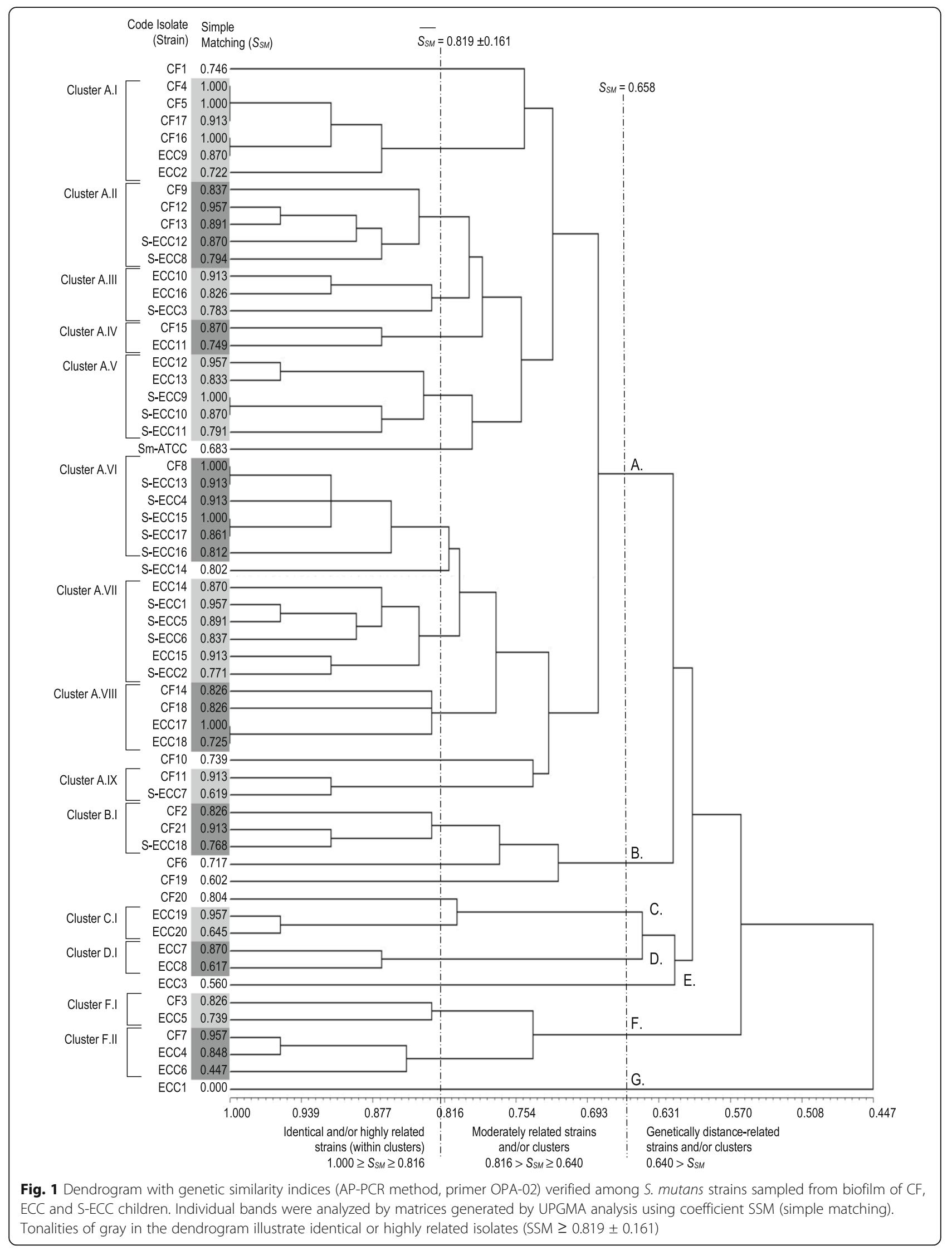




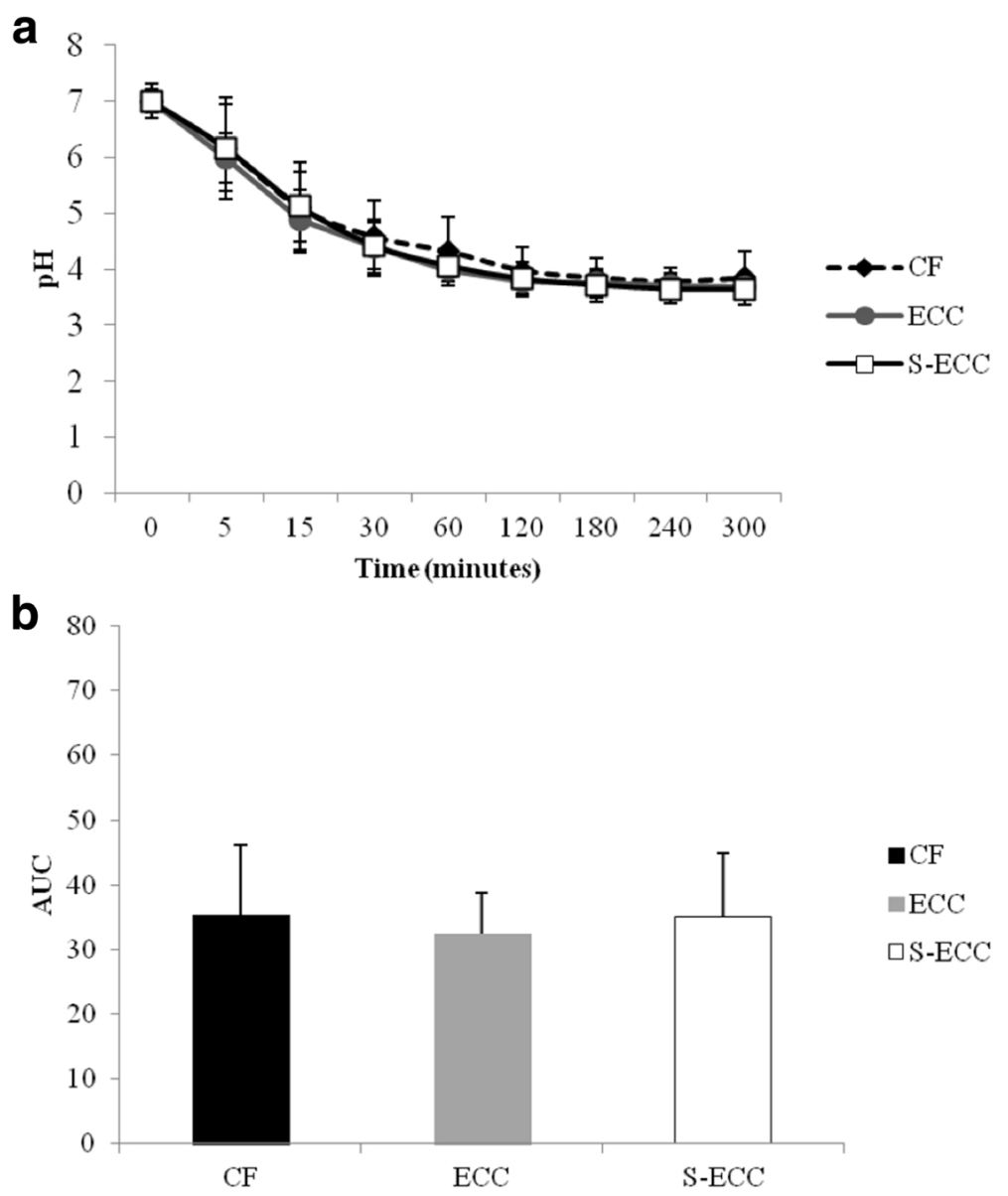

Fig. 2 Acidogenicity (acid production). a Glycolytic curves. Means of pH values through glycolysis. b Means of the area under the curve (AUC) of glycolytic pH fall. Bars denote standard deviation for both Figures $\mathbf{a}$ and $\mathbf{b}$. *No difference in pH values among CF, ECC and S-ECC genotypes, for any time point. Different uppercase letters shows statistical difference among CF, ECC and S-ECC genotypes by ANOVA test

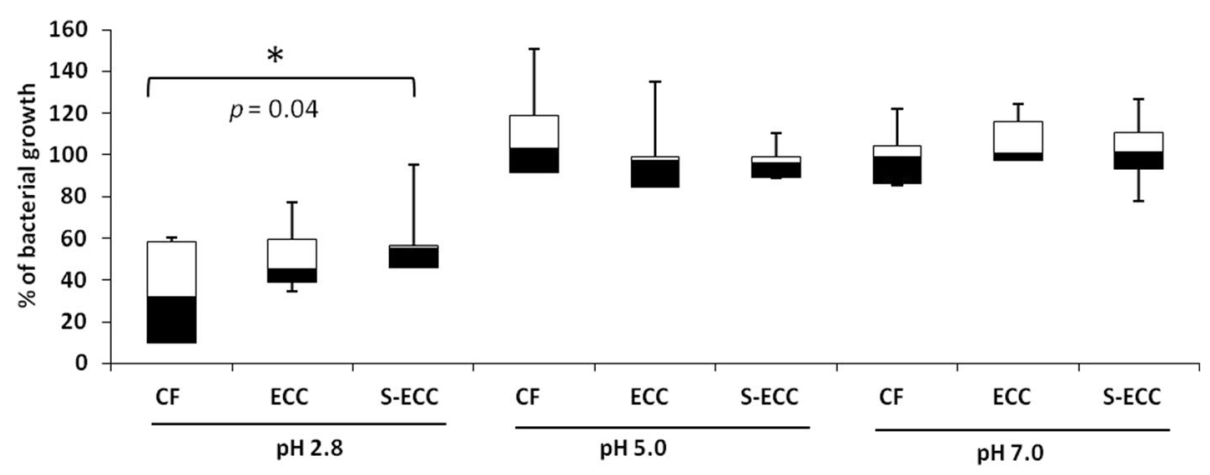

Fig. 3 Aciduricity (acid tolerance). Percentage of bacterial growth (T60) in relation to T0 (100\%) in pH 2.8, pH. 5.0 and pH 7.0. ${ }^{*}$ Statistical difference between CF and S-ECC pH by Mann-Whitney tests $(p<0.05)$. Box plots: bars indicate minimum and maximum values. Black and white boxes indicate lower and upper quartiles, respectively. Line in the middle of boxes is median 


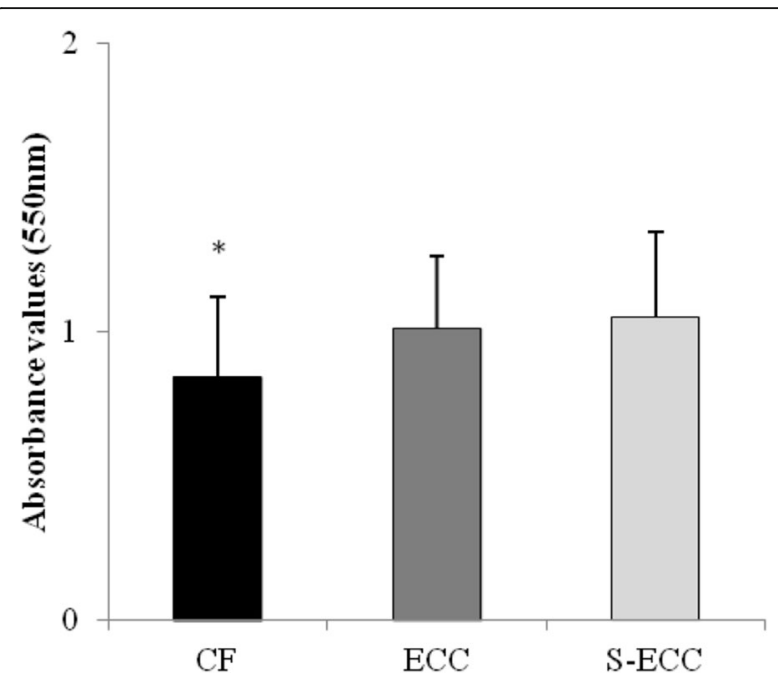

Fig. 4 Biofilm formation. Absorbance values $(550 \mathrm{~nm})$ obtained for $48 \mathrm{~h}$ biofilm of S. mutans genotypes from CF, ECC and S-ECC children. Different letters show statistical difference among the groups, according to ANOVA/Tukey tests $(p<0.05)$

Therefore, the tested hypothesis 1 was rejected. Available evidences are inconclusive regarding genotypic diversity and caries. Some studies reported a decrease in genotypic diversity in caries-active subjects or absence of difference between caries-free and caries-active children [11] while multiple genotypes were associated with caries activity in infants $[7,9]$. In the present study, no difference on $S$. mutans genotypic diversity was found in dental biofilm of caries-active and caries-free children, agreeing with aforementioned investigation [11]. Previous studies have suggested that constant sugar stress provided by dietary sugars, a condition found in caries-active individuals, may select some salivary genotypes make them more prone to colonize dental biofilms $[17,20]$. These divergences in genotypic diversities among studies could be attributed to differences in the studied population mainly in respect to their age and caries status. Additionally, altogether, these data reinforce that phenotypic traits may be more important than the presence/absence of specific genotypes in biofilm [11].

In respect to the genotyping of MS isolates, Argimón et al. [21] have suggested that $S$. mutans strains derived from caries-active or caries-free individuals cannot be differentiated only based on the presence or absence of specific genetic elements. In order to circumvent this problem, we chose AP-PCR analysis with primer OPA02 that showed a considerable number of amplicons and an efficient differentiation of genotypes. Previous studies have proved superior efficiency of OPA-02 in the identification of distinct genotypes when compared with other arbitrary primers $[6,7,11,17]$. Genetic polymorphism among closely related species is determined by changes in base pairing, by deletion or insertion of new genetic sequences and the cloning transmission from external sources [22]. Some strains of $S$. mutans can acquire various cariogenic properties and antibiotic resistance by transformation [23]. Cvitkovitch [23] suggested that bacterial transformations may occur in environments, which suffer changes and extreme fluctuations in population dynamics, such as the oral cavity. Bacteria in these environments are often exposed to different stress conditions, such as excess or lack of nutrients, low $\mathrm{pH}$, high osmolarity and the use of antimicrobial agents by the host [24]. Therefore, the natural genetic transformation could be considered an important mechanism of cell adaptation to environmental changes, providing microbial resistance, genetic variation and rapid evolution of virulence factors $[23,24]$. All these microbial traits could favor survival and proliferation and contribute in the development and/or progression of caries lesions.

A limited number of $S$. mutans genotypes (53.6\% with 2 genotypes and $35.7 \%$ with one genotype) were observed in this present study. This result is consistent with other reports $[13,14,25,26]$, which found less than 2 genotypes in dental plaque per child. Additionally, in this present study, children had complete deciduous dentition and several studies have demonstrated that $S$. mutans infections are established in the early stages of dentition development and remain stable for several years [25-27].

An important characteristic of virulence of S. mutans is its ability to metabolize a variety of dietary carbohydrates such as sucrose and produce a large amount of organic acids by fermentation, which acidify the dental biofilm. In this study, no statistical difference in relation to acidogenicity ( $\mathrm{pH}$ drop) was found among the $S$. mutans genotypes isolated from dental biofilm of $\mathrm{CF}$, ECC and S-ECC children. Previous studies reported no correlation between caries activity and in vitro acid production of $S$. mutans isolates monitored by records of final $\mathrm{pH}$ reached after sugar fermentation [7, 10]. Regarding aciduricity, our data showed that genotypes isolated from S-ECC children are more acid-tolerant under extreme acidic $\mathrm{pH}$ challenge (such as the tested $\mathrm{pH} 2.8$ condition) than those isolated from CF and ECC children. This data is in consonance with Lembo et al. [11] that demonstrated that genotypes from caries-active children presented low-susceptibility to acid challenge. However, it is important to mention that no criterion for the assessment of caries lesions severity was adopted in that study [11]. Therefore, we were able to show indeed that acid-tolerance of genotypes is increased with increased caries severity, since no difference was found in cell viability between CF and ECC children under distinct acidic environments. The frequent acidification of oral cavity as a result of sugar fermentation by biofilm microbiota is followed by expression of numerous 
proteins responsible for maintenance of cell viability by a process called acid-tolerance response - ATR [28]. This mechanism is dependent on a number of virulence traits including the ability to carry out glycolysis at a lower $\mathrm{pH}[17,20]$. The adaptation process to acidic environments in $S$. mutans is progressive, indicating not a genetic selection but a gradual physiologic process, changing membrane lipid composition, incorporating unsaturated fatty acids into the plasma membrane [29] and affecting activities of membrane ATPases [30]. $S$. mutans controls proton intracellular influx increasing proton extrusion via end-product efflux and $F_{1}-F_{0^{-}}$ ATPase activity. The $S$. mutans $\mathrm{F}_{1}-\mathrm{F}_{0}$-ATPase can operate at low $\mathrm{pH}$ much more efficiently than the ATPase of several other competing oral bacterial species such as Streptococcus salivarius and Streptococcus sanguinis [31]. Besides, S. mutans are able to encode several enzymes to protect DNA or repair DNA damage from the harmful effects of intracellular acidification [28]. As a response to all these physiological changes, the frequent $\mathrm{pH}$ fall found in oral cavity of S-ECC children allowed a more efficient acid adaptation of their S. mutans genotypes, which contributed to the enhanced aciduricity. Considering acidogenicity and aciduricity, it seems based on our results that the latter one plays a more important role on the development of cariogenic biofilms compared with the ability of strains in acid production from dietary sugars.

The present study also evaluated the ability of $S$. mutans genotypes to form in vitro biofilm in a sucroserich medium. ECC and S-ECC genotypes formed higher amount of biofilm biomass than CF genotypes. This finding corroborated with those obtained by other researches using animal model [32] and in vitro study [10]. This last study showed that $S$. mutans isolates exhibited variability in their ability to form biofilm, but five of the six high biofilm-forming isolates were obtained from caries-active children [11]. The potential to form biofilm can be also indirectly determined by the production of insoluble extracellular polysaccharides (EPS) [10]. Individuals with high caries activity are often infected by $S$. mutans strains that produce significantly higher amounts of EPS compared to strains infecting caries-free children [10] and adults [7]. EPS improve bacterial adherence to dental surfaces [10]. Additionally, EPS modify the matrix of biofilms making them more porous facilitating the diffusion of acids and carbohydrates throughout the biofilm allowing $\mathrm{pH}$ fall in tooth/biofilm interface [33]. It may be possible though that ECC and S-ECC genotypes produce more EPS than CF genotypes. This question will be addressed in further studies. Therefore, hypotheses 2 and 3 could be partially accepted.

In the current study, in agreement with Kouidhi et al. [34], we showed that the detection of S. mutans in biofilms increased depending on severity of dental caries, since all MS isolates from S-ECC children were positively identified as $S$. mutans. As discussed above, $S$. mutans are highly acidogenic, aciduric and able to form thick biofilms in the presence of sucrose. Then it is important to discuss that up to $80 \%$ of MS isolates were identified as $S$. mutans in biofilm samples of CF children which means that phenotypic traits of $S$. mutans are more important for caries development than their relative numbers in biofilms. This is supported by our data in a way that biofilm forming ability and acid tolerance were higher in genotypes isolated from ECC and S-ECC children.

\section{Conclusions}

Although genotypic diversity was similar in children, regardless of caries status, S. mutans genotypes from caries-active children were more acid-tolerant and presented higher ability to form biofilm than those isolated from caries-free children. Acid tolerance seems to be the most important $S$. mutans trait related to the pathogenesis of severe early childhood caries.

\section{Abbreviations}

AP-PCR: Arbitrary-primer polymerase chain reaction; AUC: Area under the curve; CF: Caries free; dmfs: Decayed, missing, filling teeth surface; DNTp: Deoxynucleotide solution mix; ECC: Early childhood caries; EDTA: Ethylenediamine tetraacetic acid; $\mathrm{HCl}$ : Cloridric acid:

$\mathrm{MgCl}_{2}$ : Magnesium chloride; NaCl: Sodium chloride; NTSYS: Numerical Taxonomy and Multivariate Analysis System; S-ECC: Severe early childhood caries; SSM: Simple Matching Coefficient; TaqDNA polymerase: Termus aquaticus DNA polymerase; UPGMA: Unweighted Pair-Group Method with mathematic average

\section{Acknowledgements}

Not applicable.

\section{Funding}

This study was supported by FAPESP - São Paulo Research Foundation (scholarship for VRS \#2014/02072-1) and CNPq - National Board of Scientific and Technological Development (scholarship for RMAV \#141702/2012-5) from Brazil.

\section{Availability of data and materials}

All data generated or analyzed during this study are included in this published article. They are available from the corresponding author on reasonable request.

\section{Authors' contributions}

$C D, A C B D, T C N$ and RAA conceived and designed the experiments. RMAV, KSC and VRS performed microbiological assays. CD, NHC, MLAL and MFGB performed genetic analysis. CD, RMAV, RAA and TCN analyzed data and wrote the manuscript. CD supervised the study. All authors contributed for critical revision and approved the final manuscript.

\section{Ethics approval and consent to participate}

This study was approved by the Research Ethics Committee of Araçatuba Dental School, State University of Sao Paulo, Brazil (CAAE 0041.0.258.000-10). Signed informed consent was obtained from the parents/ legal tutors of children previously to the beginning of the study.

\section{Consent for publication}

Not applicable.

Competing interests

The authors declare that they have no competing interests. 


\section{Publisher's Note}

Springer Nature remains neutral with regard to jurisdictional claims in published maps and institutional affiliations.

\section{Author details}

'Universidad Mayor de San Andrés (UMSA), Foundation Pro-Joven, La Paz, La Paz, Bolivia. ${ }^{2}$ Department of Pediatric Dentistry and Public Health, São Paulo State University (UNESP), School of Dentistry, Araçatuba, R. José Bonifácio, 1193, Araçatuba, SP CEP: 16015-050, Brazil. ${ }^{3}$ Department of Preventive Dentistry, Faculty of Dentistry, Federal University of Rio Grande do Sul, Porto Alegre, RS, Brazil. ${ }^{4}$ Department of Oral Diagnostic, Area of Microbiology and Immunology, University of Campinas (UNICAMP), School of Dentistry, Piracicaba, SP, Brazil. ${ }^{5}$ Department of Research and Postgraduate Studies, Area of Pharmacogenetics and Molecular Biology, University of Alfenas (UNIFENAS), Medicine School, Alfenas, MG, Brazil.

\section{Received: 5 February 2017 Accepted: 5 July 2017}

\section{Published online: 14 July 2017}

\section{References}

1. Marsh PD. Are dental diseases examples of ecological catastrophes? Microbiology. 2003;149(Pt 2):279-94.

2. Hamada S, Slade HD. Biology, immunology, and cariogenicity of Streptococcus mutans. Microbiol Rev. 1980 Jun;44(2):331-84.

3. Marsh PD. Dental plaque as a biofilm: the significance of $\mathrm{pH}$ in health and caries. Compend Contin Educ Dent. 2009;30:76-8. 80, 83-7; quiz 88, 90

4. American Academy of Pediatric Dentistry: Policy on Early Childhood Caries (ECC): Classifications, Consequences, and Preventive Strategies. Reference Manual Revised. Pediatr Dent. 2008-2009;30(7 Suppl):40-3.

5. Ng MW, Chase I. Early childhood caries: risk-based disease prevention and management. Dent Clin N Am. 2013;57:1-16.

6. Tabchoury CP, Sousa MC, Arthur RA, Mattos-Graner RO, Del Bel Cury AA, Cury JA. Evaluation of genotypic diversity of Streptococcus mutans using distinct arbitrary primers. J Appl Oral Sci. 2008;16:403-7.

7. Napimoga MH, Kamiya RU, Rosa RT, et al. Genotypic diversity and virulence traits of Streptococcus mutans in caries-free and caries-active individuals. J Med Microbiol. 2004:53:697-703.

8. Alaluusua S, Mättö J, Grönroos L, Innilä S, Torkko H, Asikainen S, JousimiesSomer $\mathrm{H}$, Saarela M. Oral colonization by more than one clonal type of mutans streptococcus in children with nursing-bottle dental caries. Arch Oral Biol. 1996:41:167-73.

9. Zhou Q, Qin X, Qin M, Ge L. Genotypic diversity of Streptococcus mutans and Streptococcus sobrinus in 3-4-year-old children with severe caries or without caries. Int J Paediatr Dent. 2011:21:422-31.

10. Mattos-Granner RO, Smith DJ, King WF, Mayer MPA. Water insoluble glucan synthesis by mutans streptococcal strains correlates with caries incidence in 12 to 30 month old children. J Dental Res. 2000;79:1371-7.

11. Lembo FL, Longo PL, Ota-Tsuzuki C, Rodrigues CR, Mayer MP. Genotypic and phenotypic analysis of Streptococcus mutans form different oral cavity sites of caries-free and caries-active children. Oral Microbiol Immunol. 2007:22:313-9.

12. Momeni SS, Whiddon J, Cheon K, Ghazal T, Moser SA, Childers NK. Genetic Diversity and Evidence for Transmission of Streptococcus mutans by DiversiLab rep-PCR. J Microbiol Methods. 2016;128:108-17.

13. Cheon K, Moser SA, Wiener HW, Whiddon J, Momeni SS, Ruby JD, Cutter GR, Childers NK. Characteristics of Streptococcus mutans genotypes and dental caries in children. Eur J Oral Sci. 2013;121:148-55.

14. Cheon K, Moser SA, Whiddon J, Osgood RC, Momeni S, Ruby JD, Cutter GR, Allison DB, Childers NK. Genetic diversity of plaque mutans streptococci with rep-PCR. J Dent Res. 2011;90:331-5.

15. Nascimento MM, Lemos JAC, Abranches J, Goncalves RB, Burne RA. Adaptive acid tolerance response of Streptococcus sobrinus. J Bacteriol. 2004;186:6383-90

16. Duque C, Negrini TC, Sacono NT, Boriollo MFG, Hofling JF, Hebling J, Spolidorio DMP. Genetic polymorphism of Streptococcus mutans strains associated with incomplete caries removal. Braz J Oral Sci. 2009:8(1):2-8.

17. Arthur RA, Del Bel Cury AA, Mattos-Graner RO, et al. Genotypic and phenotypic analysis of $\mathrm{S}$ mutans isolated from dental biofilms formed in vivo under high cariogenic conditions. Braz Dent J. 2011;22:267-74.

18. Belli WA, Marquis RE. Adaptation of Streptococcus mutans and Enterococcus hirae to acid stress in continuous culture. Appl Environ Microbiol. 1991;57:1134-8.
19. Mattos-Graner RO, Jin S, King WF, Chen T, Smith DJ, Duncan MJ. Cloning of the Streptococcus mutans gene encoding glucan binding protein B and analysis of genetic diversity and protein production in clinical isolates. Infect Immun. 2001;69:6931-41.

20. Arthur RA, Tabchoury CP, Mattos-Graner RO, Cury AADB, Leme AFP, Vale GC Cury JA. Genotypic diversity of S. mutans in dental biofilm formed in situ under sugar stress exposure. Braz Dent J. 2007;18:185-91.

21. Argimón S, Konganti $\mathrm{K}$, Chen H, Alekseyenko AV, Brown S, Caufield PW. Comparative genomics of oral isolates of Streptococcus mutans by in silico genome subtraction does not reveal accessory DNA associated with severe early childhood caries. Infect Genet Evol. 2014:21:269-78.

22. Hohwy J, Reinholdt J, Kilian M. Population dynamics of Streptococcus mitis in its natural habitat. Infect Immun. 2001;69:6055-63.

23. Cvitkovitch DG. Genetic competence and transformation in oral streptococci. Crit Rev Oral Biol Med. 2001;12:217-43.

24. Li YH, Lau PC, Lee JH, Ellen RP, Cvitkovitch DG. Natural genetic transformation of Streptococcus mutans growing in biofilms. J Bacteriol. 2001;183:897-908.

25. Redmo Emanuelsson IM, Carlsson P, Hamberg K, Bratthall D. Tracing genotypes of mutans streptococci on tooth sites by random amplified polymorphic DNA (RAPD) analysis. Oral Microbiol Immunol. 2003;18:24-9.

26. Klein MI, Florio FM, Pereira AC, Hofling JF, Goncalves RB. Longitudinal study of transmission, diversity, and stability of Streptococcus mutans and Streptococcus sobrinus genotypes in Brazilian nursery children. J Clin Microbiol. 2004;42:4620-6.

27. Alaluusua S, Alaluusua SJ, Karjalainen J, Saarela M, Holttinen T, Kallio M, Holtta P, Torkko H, Relander P, Asikainen S. The demonstration by ribotyping of the stability of oral Streptococcus mutans infection over 5 to 7 years in children. Arch Oral Biol. 1994;39:467-71.

28. Matsui $R$, Cvitkovitch D. Acid tolerance mechanisms utilized by Streptococcus mutans. Future Microbiol. 2010;5:403-17.

29. Fozo EM, Quivey RG Jr. The fabM gene product of Streptococcus mutans is responsible for the synthesis of monounsaturated fatty acids and is necessary for survival at low pH. J Bacteriol. 2004;186:4152-8.

30. Bowden GH, Hamilton IR. Competition between Streptococcus mutans and Lactobacillus casei in mixed continuous culture. Oral Microbiol Immunol. 1989:4:57-64.

31. Bender GR, Sutton SV, Marquis RE. Acid tolerance, proton permeabilities, and membrane ATPases of oral streptococci. Infect Immun. 1986;53(2):331-8.

32. Köhler B, Krasse B. Human strains of mutans streptococci show different cariogenic potential in the hamster model. Oral Microbiol Immunol. $1990 \cdot 5 \cdot 177-80$

33. Zero DT, van Houte J, Russo J. The intra-oral effect on enamel demineralization of extracellular matrix material synthesized from sucrose by Streptococcus mutans. J Dent Res. 1986;65:918-23.

34. Kouidhi B, Fdhila K, Slama RB, Mahdouani K, Hentati H, Najjari F, Bakhrouf A, Chaieb K. Molecular detection of bacteria associated to dental caries in 4 and 12-year-old Tunisian children. Microb Pathog. 2014;71-2:32-6.

\section{Submit your next manuscript to BioMed Central and we will help you at every step:}

- We accept pre-submission inquiries

- Our selector tool helps you to find the most relevant journal

- We provide round the clock customer support

- Convenient online submission

- Thorough peer review

- Inclusion in PubMed and all major indexing services

- Maximum visibility for your research

Submit your manuscript at www.biomedcentral.com/submit
C) Biomed Central 